\title{
Brain Abscess Caused by Gemella Morbillorum: Case Report and Review of the Literature
}

\author{
Gemella Morbillorum Nedenli Beyin Apsesi: Olgu Sunumu ve \\ Literatür Taramast
}

Silky CHOTAI, Hong-Joo MOON, Joo-Han KIM, Jong-Hyun KIM, Hung-Seob CHUNG, Youn-Kwan PARK, Taek-Hyun KWON

Korea University Guro Hospital, Department of Neurosurgery, Seoul, Korea

Correspondence address: Kwon TAEK-HYUN / E-mail: drsilkypranit@gmail.com

\begin{abstract}
We describe a rare case of cerebral abscess in an immunocompetent 67-year-old male with Gemella morbillorum as the causative agent. Gemella morbillorum is an aerobic gram positive coccus and is deemed to be a normal inhabitant of the oral cavity. The aim of this report is to introduce Gemella morbillorum as the emerging pathogen involved in brain abscesses. To the best of our knowledge only eight cases of Gemella morbillorum brain abscess have been reported in the literature. An exhaustive review of the literature is included with emphasis on the primary source of infection, clinical presentation, radiological diagnosis, and treatment modalities.
\end{abstract}

KEYWORDS: Brain abscess, Gemella morbillorum, Odontogenic infections, Immunocompetent, Latency

öz

İmmünokompetan 67 yaşında bir erkek hastada etkenin Gemella morbillorum olduğu nadir bir serebral apse vakası sunuyoruz. Gemella morbillorum aerobik gram pozitif koktur ve normalde oral kavitede bulunur. Bu raporun amacı, Gemella morbillorum'un beyin apselerinde giderek saptanmakta olan bir patojen olarak belirlenmesidir. Bildiğimiz kadarıla literatürde sadece sekiz Gemella morbillorum beyin apsesi olgusu mevcuttur. Primer enfeksiyon kaynağı, klinik sunum, radyolojik tanı ve tedavi modaliteleri vurgulanarak literatür kapsamlı bir şekilde gözden geçirilmiştir.

ANAHTAR SÖZCÜKLER: Beyin apsesi, Gemella morbillorum, Odontojenik enfeksiyonlar, İmmünkompetan, Latans

\section{INTRODUCTION}

A brain abscess represents a potentially life-threatening condition for which immediate correct diagnosis and treatment should be called for. Brain abscesses are often polymicrobial infections. The most frequent causative agents are streptococcus and anaerobic microorganisms (4). Gemella morbillorum is rarely the cause of a brain abscess and a review of the literature could garner only eight such cases (3). Gemella species are facultative aerobic gram positive cocci which are deemed to be the normal inhabitant of the mucous membranes of the oropharynx, and the gastrointestinal, upper respiratory and female genital tracts $(1,5,15)$. Infections due to Gemella morbillorum are unusual and not associated with a preferential anatomical location, although bacteremia and infective endocarditis predominate (5). We describe a 67-year-old immunocompetent male case with a previous history of periodontitis who developed frontal lobe abscess caused by Gemella morbillorum as a single isolate, and review the pertinent literature.

\section{CASE REPORT}

A 67-year-old male presented at our department with complaints of inability to move the left upper and lower limbs for the last 5 days. He had no complains of fever, headache, bowel or bladder disturbances. His past medical history was significant for esophagus carcinoma diagnosed in 2001 for which he was treated with surgery, chemotherapy and radiotherapy. He had a history of periodontitis 12 years back which was treated completely and a recent dental examination unveiled periodontitis. Neurological examination was significant for hypertonia and rigidity in the left extremities. Sensory examination was normal. Laboratory examination revealed a leucocyte count of $8700 / \mathrm{mm}^{3}$, ESR of $21 \mathrm{~mm} /$ hour and CRP of $8.9 \mathrm{mg} / \mathrm{dl}$. Blood culture was negative. No signs of sinusitis and or mastoditis were documented by CT scan and a chest X-ray did not reveal any pulmonary lesion. Echocardiogram documented no evidence of endocarditis.

CT scan of the brain with contrast showed a rim-enhancing right frontal lobe mass, measuring $27 \mathrm{~mm}$ in diameter with perilesional edema (Figure 2A,B). Diffusion-weighted magnetic resonance imaging demonstrated a large ovoid 
mass with high signal intensity in the upper aspect of the right frontal lobe. This finding was corraborated with the low signal intensity on the apparent diffusion coefficient mapping (Figure $1 \mathrm{~A}-\mathrm{C}$ ). A diagnosis of cerebral abscess inthe right frontal lobe was established. Intravenous antibiotics such as metronidazole and ceftriaxone were initiated. A short course of steroids was used to reduce the mass effect from the lesion.

Surgical drainage of the abscess with the excision of the capsule was achieved by the transcortical approach. Postoperative CT scan showed no complications. Laboratory analysis of the aspirate identified Gemella morbillorum as the pathogen implicated in the infection. Recovery from the surgery was uneventful and a gradual clinical improvement was noted. Antibiotic therapy was continued for six weeks postoperatively. Dental referral for treatment of the periodontitis was undertaken. CT scan at one month follow up documented hypodensity in the right frontal lobe (Figure $2 A, B)$. At six-month follow up the patient was neurologically intact with no recurrence.

\section{DISCUSSION}

Infections of central nervous system by Gemella species are unusual and the brain abscesses reported in the literature include the description of only eight cases (Table I). Gemella morbillorum was first described in 1917 by Tunicliff (15).The clinical significance of infections by Gemella species has not gained much attention until the early eighties, when Ariza et al isolated the organism from intracranial suppuration (1). Since then it has been isolated frequently in cases of endocarditis and septic shock (5).

The identification of primary source of infection in reported cases of Gemella morbillorum brain abscess revealed odontogenic infections and dental procedures in the past history of $62.5 \%$ of the patients $(2,9-11,14)$. Indeed, in our case periodontitis was noted in the past history. As there was no evidence of sinusitis or other systemic infection, an odontogenic focus was reckoned as the source of infection. Although it is well comprehended that oral pathogens are common source of infection for gemella brain abscess, other

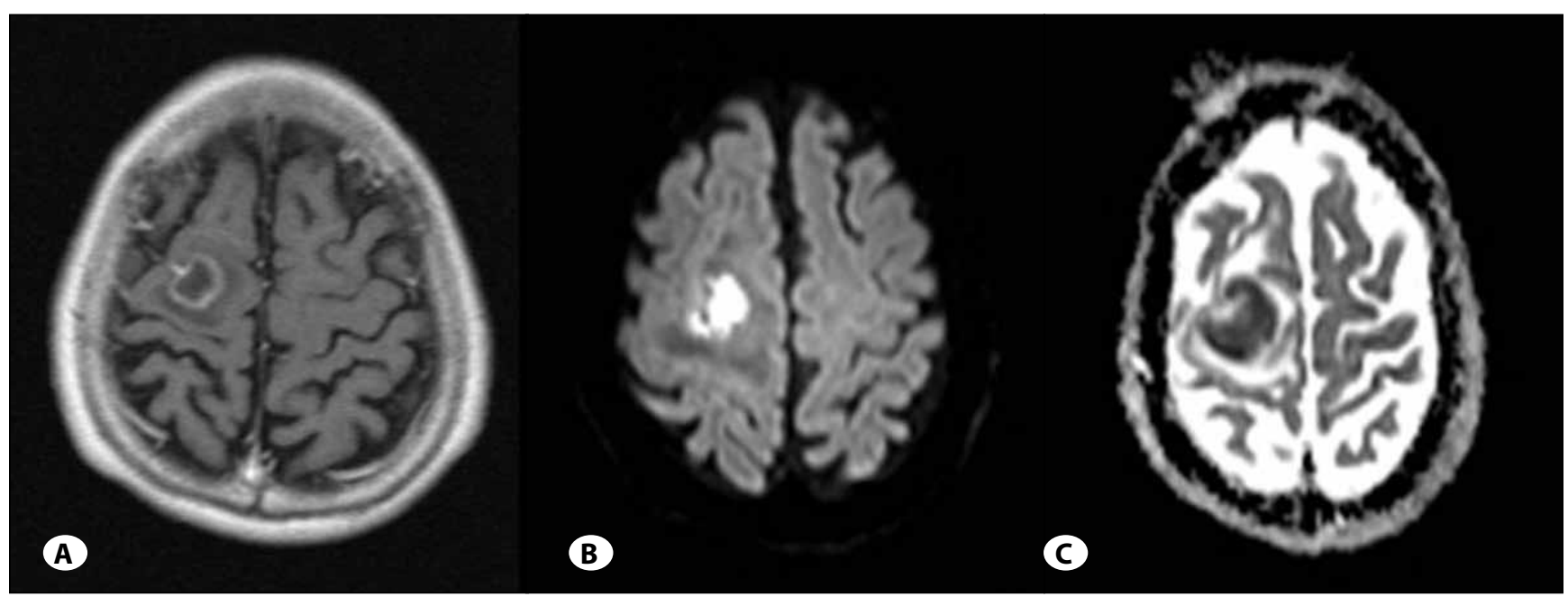

Figure 1: A) Preoperative axial T1-weighted image showing a rim-enhanced mass in the right frontal lobe with perilesional edema. B) Diffusion-weighted MR Image showing hyperintense ovoid mass in the right frontal lobe C) Apparent diffusion coefficient showing low intensity in the right frontal lobe.

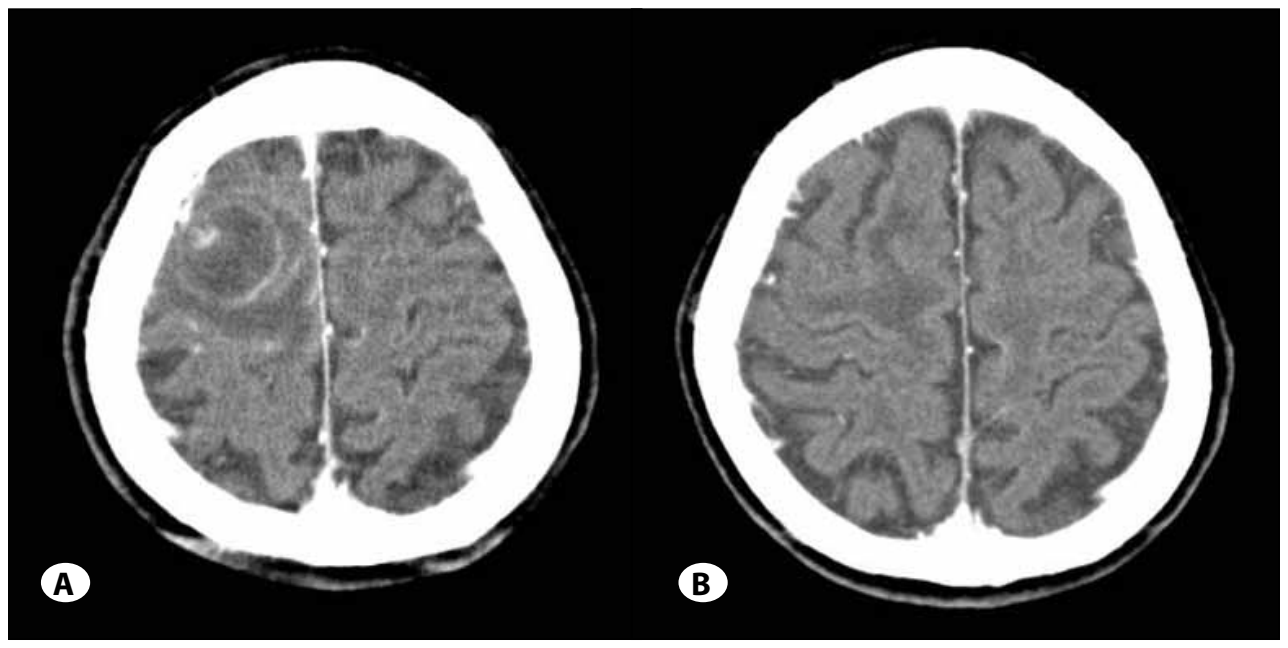

Figure 2: A) Preoperative contrast CT scan showing heterogeneous mass with rim enhancement. B) Postoperative CT scan showing hypodensity in the right frontal lobe with no enhancement due to residual mass. 
Table I: Summary of Reported Cases of Gemella Morbillorum Brain Abscess Till 2010

\begin{tabular}{|c|c|c|c|c|c|c|c|c|}
\hline & Reference & $\begin{array}{l}\text { Primary } \\
\text { infection }\end{array}$ & $\begin{array}{l}\text { Intracranial } \\
\text { location }\end{array}$ & $\begin{array}{l}\text { Clinical } \\
\text { presentation }\end{array}$ & Laboratory findings & Treatment & $\begin{array}{l}\text { Operative } \\
\text { modality }\end{array}$ & Outcome \\
\hline 1 & $\begin{array}{l}\text { Asensi et al (2), } \\
1996,57 / M\end{array}$ & Periodontitis & $\begin{array}{l}\text { Fronto } \\
\text { parieto } \\
\text { temporal }\end{array}$ & $\begin{array}{l}\text { Fever, headache, } \\
\text { hemiparesis }\end{array}$ & No Comment & Imipenem & $\begin{array}{l}\text { Needle } \\
\text { aspiration }\end{array}$ & cure \\
\hline 2 & $\begin{array}{l}\text { Murray et al (13) } \\
1998,45 / \mathrm{M}\end{array}$ & $\begin{array}{l}\text { Septic } \\
\text { arthritis }\end{array}$ & Frontal & Acute meningitis & No Comment & $\begin{array}{l}\text { Ceftriaxone, } \\
\text { metronidazole, } \\
\text { gentamycin }\end{array}$ & $\begin{array}{l}\text { Ultrasound- } \\
\text { guided } \\
\text { resection }\end{array}$ & cure \\
\hline 3 & $\begin{array}{l}\text { Messori et al (11), } \\
2002,28 / M\end{array}$ & $\begin{array}{l}\text { Sinusitis } \\
\text { Dental } \\
\text { extraction }\end{array}$ & $\begin{array}{l}\text { Fronto } \\
\text { parietal }\end{array}$ & $\begin{array}{l}\text { Fever, headache, } \\
\text { neck stiffness }\end{array}$ & WBC $-15,5050 / \mathrm{mm}^{3}$ & $\begin{array}{l}\text { Vancomycin, } \\
\text { chloramphenicol }\end{array}$ & $\begin{array}{l}\text { Stereotactic } \\
\text { aspiration }\end{array}$ & cure \\
\hline 4 & $\begin{array}{l}\text { Spangnoli et al } \\
(14), 2003,47 / M\end{array}$ & $\begin{array}{l}\text { Dental } \\
\text { abscess }\end{array}$ & $\begin{array}{l}\text { Fronto } \\
\text { parietal }\end{array}$ & $\begin{array}{l}\text { Fever, headache, } \\
\text { hemiparesis }\end{array}$ & $\begin{array}{l}\text { WBC } 9800 / \mathrm{mm}^{3} \\
\text { ESR }-60 \mathrm{~mm} / \mathrm{h}\end{array}$ & $\begin{array}{l}\text { Amoxicillin, } \\
\text { Clavulanic acid }\end{array}$ & $\begin{array}{l}\text { Needle } \\
\text { aspiration }\end{array}$ & cure \\
\hline 5 & $\begin{array}{l}\text { Spangnoli et al } \\
(14), 2003,40 / M\end{array}$ & none & Frontal & $\begin{array}{l}\text { Fever, Seizure, } \\
\text { gait and speech } \\
\text { disturbances }\end{array}$ & $\begin{array}{l}\text { WBC- } 11,000 / \mathrm{mm}^{3} \\
\text { ESR }-99 \mathrm{~mm} / \mathrm{h}\end{array}$ & $\begin{array}{l}\text { Amoxicillin, } \\
\text { Clavulanic acid }\end{array}$ & $\begin{array}{l}\text { Needle } \\
\text { aspiration }\end{array}$ & cure \\
\hline 6 & $\begin{array}{l}\text { Liberto et al (9) } \\
2006,75 / F\end{array}$ & $\begin{array}{l}\text { Dental } \\
\text { abscess, } \\
\text { pleuritis }\end{array}$ & Frontal & $\begin{array}{l}\text { Fever, headache, } \\
\text { vomiting }\end{array}$ & $\begin{array}{l}\text { WBC }-12,000 / \mathrm{mm}^{3} \\
\text { ESR }-60 \mathrm{~mm} / \mathrm{h}\end{array}$ & $\begin{array}{l}\text { Amoxicillin, } \\
\text { clindamycin }\end{array}$ & $\begin{array}{l}\text { Stereotactic } \\
\text { aspiration }\end{array}$ & cure \\
\hline 7 & $\begin{array}{l}\text { Lopes et al (10), } \\
2007,50 / \mathrm{M}\end{array}$ & $\begin{array}{l}\text { Dental } \\
\text { procedure }\end{array}$ & Cerebellar & $\begin{array}{l}\text { Fever, headache, } \\
\text { gait ataxia }\end{array}$ & $\mathrm{WBC}-12,000 / \mathrm{mm}^{3}$ & $\begin{array}{l}\text { Vancomycin, } \\
\text { cephalosporin, } \\
\text { Metronidazole }\end{array}$ & $\begin{array}{l}\text { Surgical } \\
\text { excision }\end{array}$ & cure \\
\hline 8 & $\begin{array}{l}\text { Benedetti et al (3) } \\
2010,77 / \mathrm{M}\end{array}$ & none & $\begin{array}{l}\text { Cerebellar, } \\
\text { multiple }\end{array}$ & $\begin{array}{l}\text { Fever, headache, } \\
\text { gait ataxia }\end{array}$ & No comment & $\begin{array}{l}\text { Multiple } \\
\text { combinations }\end{array}$ & $\begin{array}{l}\text { Surgical } \\
\text { excision }\end{array}$ & death \\
\hline 9 & $\begin{array}{l}\text { Our case, 2010, } \\
67 / M\end{array}$ & Periodontitis & Frontal & Hemiparesis & $\begin{array}{l}\text { WBC }-8700 / \mathrm{mm}^{3} \\
\text { ESR }-21 \mathrm{~mm} / \mathrm{hour} \\
\mathrm{CRP}-8.9 \mathrm{mg} / \mathrm{dl}\end{array}$ & $\begin{array}{l}\text { Ceftriaxone, } \\
\text { metronidazole }\end{array}$ & $\begin{array}{l}\text { Surgical } \\
\text { excision }\end{array}$ & cure \\
\hline
\end{tabular}

sources cannot be underestimated. Murray et al described septic arthritis (13) as the primary source; whereas in reports of Benedetti et al (3) and Spagnoli et al (14) the possible source of infection remains unidentified.

The intracranial abscesses in $87.5 \%$ of reported cases were confined to one anatomical location. The frontal lobe was reported to be the most common inoculated site (75\%). Our case presented with a single large ovoid abscess in the right frontal lobe. It is well recognized that the oral pathogens and infections of the frontal and ethmoidal sinuses have a predilection towards frontal lobe (4). However, two recent publications by Lopes et al (10) and Benedetti et al (3) describe a gemella abscess in the cerebellum.

The oral pathogens are frequently demonstrated to cause brain abscesses in immunocompromised patients (8). In contrast, including our case, all but one of the reported cases were immunocompetent $(2-3,9-11,14)$. This underscores the fact that the pathogenic potential of gemella species cannot be underestimated. The pathological factors entailed in the causation of brain abscess and the spread of Gemella morbillorum to the central nervous system in immunocompetent patients remain unidentified.

The presenting symptoms and signs in each reported case of gemella brain abscess were variable (Table I). Majority of the patients (75\%) had been symptomatic for a week. Nevertheless, a more acute presentation as in our case was reported by Messori et al (11) and Spangoli et al (14). Headache and fever were the most common presenting symptom and found in all (100\%) patients. Focal neurological deficit which included hemiparesis, gait ataxia, and speech disturbances was found in $87.5 \%$ of the cases $(2-3,9,11,13-14)$. Our patient however, presented with left hemiparesis without any signs of fever or headache. Such a clinical presentation without any signs of infection could be misleading and might delay the initiation of treatment. Of note is the clinical course in the report by Benedetti et al, (3) where the patient developed acute meningieal infection followed shortly by suppuration in the cerebral parenchyma. A similar pattern was reported by Murray et al (13). Both of these reports of biphasic clinical course suggest a latent survival of Gemella morbillorum, probably within the CNS, despite systemic antibiotic therapy.

Differential diagnosis of gemella brain abscess in our case included malignant brain tumor. In view of absent clinical signs of infection, the initial CT scan might be misdirecting towards a brain tumor. However, the diffusion-weighted MR imaging documenting the central core of restricted diffusion within the hyperintense lesion with low signal intensity on apparent diffusion coefficient mapping pointed convincingly to the cerebral abscess. 
The antibiotic of choice is the combination of a thirdgeneration cephalosporin (cefotaxime or ceftriaxone) plus metronidazole. The majority of the reported cases were cured with this empiric antibiotic combination. However, a few reports document the use of other antibiotic such as vancomycin, clindamycin and a combination of amoxicillin and clavulinc acid, showing the diverse antibiotic sensitivity of gemella $(2-3,9-11,14)$. Although metronidazole susceptibility is a controversial issue in therapy for gemella infections, the broad spectrum antimicrobial activity, good tissue penetrability, moderate adverse effects and low cost justify its use in gemella brain abscess (7). Indeed, the initial treatment with ceftriaxone and metronidazole did suffice in our patient. Spangoli et al, in two reported cases, continued the antibiotic for 3 weeks and the 6-month follow up showed no recurrence. In contrast, Benedetti et al and Murray et al reported gemella brain abscess after 3 weeks of antibiotic therapy for gemella meningitis. In anticipation of complete eradication of the gemella, it is needs to be emphasized that whatever regimen is used, it should be continued for a period not less than 6 weeks, (12) or continued till the $C$ reactive protein falls to normal levels (6).

The optimal management of gemella brain abscess depends largely on the anatomical location, multiplicity and pathological staging of brain abscess (13). As well comprehended, CT guided stereotactic aspiration is the modality of choice with deep seated and multiple abscesses $(9,11-12)$. Messori et al (11) reports the use of stereotactic aspiration in a patient with a fronto parietal abscess, who then developed a cortical lesion at the site of the needle procedure. In our case and in the report of Lopes et al (10), surgical excision resulted in complete cure with no recurrences. Benedetti et al (3) describes the worsening septic state two weeks following surgical excision of the abscess cavity. The autopsy report documented diffuse cerebritis and multiple abscesses in the cerebellum. Definitive management of the primary focus was performed in the majority of reports $(2,9-11,14)$.

In all of the cases of brain abscess due to Gemella morbillorum infection, the outcome was favorable except in one fatal case with a single large abscess in the cerebellum with multiple small foci detected on autopsy (3). Follow-up at 6 months in our case did not reveal any residual morbidity or recurrence and the patient is neurologically intact.

\section{CONCLUSIONS}

In summary, our immunocompetent patient developed a sudden neurological compromise, which was attributed to the frontal brain abscess caused by Gemella morbillorum. Together with the other reports cited in the literature, this report corroborates the pathological potential of these bacteria. Our findings suggest that patients who develop a brain abscess and who have a previous history of odontogenic infections may be infected with Gemella morbillorum. Since it often occurs spontaneously, presents with varied clinical presentation and might be associated with latency, a timely diagnosis, complete medical and surgical treatment, periodic follow up with identification and eradication of the primary source should be emphasized.

\section{REFERENCES}

1. Ariza J, Casanova A, Fernandez Viladrich $P$, Linares J, Pallares R, Rufi G, Verdaguer R, Gudiol F: Etiological agent and primary source of infection in 42 cases of focal intracranial suppuration. J Clin Microbiol 24: 899-902, 1986

2. Asensi V, Carton JA, Maradona JA, Asensi JM, Perez F, Redondo P, Lopez A, Arribas JM: Therapy of brain abscess with imipenem--a safe therapeutic choice? J Antimicrob Chemother 37: 200-203, 1996

3. Benedetti $P$, Rassu M, Branscombe $M$, Sefton A, Pellizzer G: Gemella morbillorum: An underestimated aetiology of central nervous system infection? J Med Microbiol 58: 1652-1656, 2009

4. Calfee DP, Wispelwey B: Brain abscess. Semin Neurol 20: 353-360, 2000

5. Debast SB, Koot R, Meis JF: Infections caused by Gemella morbillorum. Lancet 342: 560, 1993

6. Hirschberg $\mathrm{H}$, Bosnes $\mathrm{V}$ : C-reactive protein levels in the differential diagnosis of brain abscesses. J Neurosurg 67: 358-360, 1987

7. Kuriyama T, Karasawa T, Nakagawa K, Yamamoto E, Nakamura S: Bacteriology and antimicrobial susceptibility of grampositive cocci isolated from pus specimens of orofacial odontogenic infections. Oral Microbiol Immunol 17: 132-135, 2002

8. Li X, Tronstad L, Olsen I: Brain abscesses caused by oral infection. Endod Dent Traumatol 15: 95-101, 1999

9. Liberto MC, Matera G, Puccio R, Barbieri V, Quirino A, Capicotto R, Guadagnino V, Pardatscher K, Foca A: An unusual case of brain abscess by Gemella morbillorum. Jpn J Infect Dis 59: 126-128, 2006

10. Lopes A, Providencia R, Pais RP, Frade MJ, Chaddad Neto F, Oliveira E: Cerebellar abscess by Gemella morbillorum in a patient with inter-atrial communication. Arq Neuropsiquiatr 65: 1022-1025, 2007

11. Messori A, Bartolucci F, Dini M, Paggi AM, Ricciuti RA, Rychlicki F, Salvolini U: Gemella morbillorum deep brain abscess successfully treated with combined stereotactic, medical, and imaging approach. Eur J Radiol 44: 143-151, 2002

12. Moorthy RK, Rajshekhar V: Management of brain abscess: An overview. Neurosurg Focus 24: E3, 2008

13. Murray CK, Hospenthal DR, Grimberg BT, Gasser RAJ: Gemella morbillorum brain abscess presenting as acute meningitis. Infectious Diseases in Clinical Practice 7: 477-479, 1998

14. Spagnoli D, Innocenti L, Ranzi ML, Tomei G, Villani RM: Cerebral abscess due to Gemella morbillorum. Eur J Clin Microbiol Infect Dis 22: 515-517, 2003

15. Tunnicliff R: The Cultivation of a micrococcus from blood in pre-eruptive and eruptive stages of measles. J Am Med Assoc LXVIII: 1028-1030, 1917 